\title{
Receptors for Insulin-like Growth Factor (IGF)-II/cation-independent Mannose-6-phosphate Are Present in Mouse Neurons and Influenced by IGF-II Treatment
}

\author{
Shigeko Fushimi ${ }^{1}$, Yoshihiro Konishi ${ }^{2}$ and Teruo Shirabe ${ }^{1}$ \\ 'Department of Neuropathology, Kawasaki Medical School, 577 Matsushima, Kurashiki, Okayama 701-0192, Japan and \\ ${ }^{2}$ Department of Clinical Research, Nishi-tottori National Hospital, 876 Mitsu, Tottori, Tottori 689-0203, Japan
}

Received June 13, 2003; accepted May 10, 2004

We investigated the cellular and sub-
cellular localization of IGF-II receptors
in the adult mouse central nervous
system (CNS). The IGF-II receptor and
the cation-independent (CI) mannose-6-
phosphate (M6P) receptor are identical.
Immunohistochemistry demonstrated that
IGF-II/CI-M6P receptor immunoreactivity
was mostly restricted to middle- to large-
sized neurons throughout the CNS. A
small number of glial cells were weakly
to moderately labeled. IGF-II/CI-M6P
receptor immunoreactivity was largely
recognized within endosome-lysosomal
structures in the neurons by immuno-
electron microscopy (EM) of the CNS
tissues. More intense labeling was
observed in larger neurons that included
more abundant endosome-lysosomal
structures, indicating that IGF-II/CI-M6P
receptor immunoreactivity reflects the

endosome-lysosomal activity specifically present in neurons. These results are consistent with the general assumption that IGF-II/CI-M6P receptors are involved in sorting lysosomal enzymes within cells. IGF-II/CI-M6P receptors also endocytose secreted IGF-II and M6P-containing glycoproteins as scavenger receptors. Furthermore, it has been reported that they are involved in the development of transmembrane IGF-II signals. Therefore, we next tried to determine if they are expressed on the cell surface of primary cultured cortical neurons. By immunofluorescence and immuno-EM, particularly by immunoscanning EM, expression of IGF-II/CI$M 6 P$ receptors was demonstrated in the neuronal cell surface in response to IGFII treatment.

Key words: insulin-like growth factor II, insulin-like growth factor II receptor, mannose-6phosphate receptor, lysosome, endosome

\section{Introduction}

IGF-II is a 67-amino acid polypeptide with substantial structural similarity to proinsulin, that is synthesized in numerous organs and tissues during fetal development [4]. Its synthesis in adults is largely restricted to the CNS, and maintains a certain high level similar to that in the embryonic CNS [23]. The major sites for IGF-II synthesis are the choroid plexus and leptomeninges, irrespective of age [10]. In addition to its effect on epithelial cells in the choroid plexus [21], it is thought to play important roles in prolifera-

Correspondence to: Yoshihiro Konishi, Department of Clinical Research, Nishi-Tottori National Hospital, 876 Mitsu, Tottori, Tottori 689-0203, Japan. E-mail: ykonishi@nishitori.hosp.go.jp tion, differentiation, maintenance of function, and repair in the CNS $[4,5,10]$. Its physiological role in the CNS, however, has yet to be concretely or systematically demonstrated.

Basically, the pleiotrophic function of IGF-II is mediated by type 1 IGF receptors (referred to as IGF-I receptors) rather than by type 2 IGF receptors (referred to as IGF-II receptors) $[4,7]$, and IGF-I receptors bind IGF-II and IGF-I with almost equal affinity [7]. It is well known that the IGFII receptors to the CI-M6P receptors are identical [18]. IGFII/CI-M6P receptors can recognize both IGF-II and M6P in their different domains [22]. It is generally accepted that they are involved not only in sorting newly synthesized lysosomal enzymes from trans Golgi reticulum to lysosomes [7], but also in the endocytosis of exogenous M6P-containing glycoproteins [17]. Therefore, they may function as non- 
signaling receptors for sorting or scavenging excess IGF-I and IGF-II signals [5]. The physiological role of IGF-II/CI$\mathrm{M} 6 \mathrm{P}$ receptors in developing transmembrane IGF-II signals is still controversial [7, 10].

To date, however, several reports have suggested that IGF-II/CI-M6P receptors actually participate in developing transmembrane IGF-II signals into target cells [11] and mediate metabolic responses to IGF-II in both neurons [13, 14] and non-neuronal cells [19]. There have also been several reports demonstrating that even M6P-containing glycoproteins activate intracellular signal transduction systems $[5,7,20]$.

As a result, several questions have arisen regarding the physiological role of IGF-II and its IGF-II/CI-M6P receptors in the CNS, including (i) What is the major biological function of IGF-II in the CNS? (ii) Which receptor, the IGF-II receptor or the IGF-I receptor, is the functional receptor mediating the physiological responses to IGF-II in the CNS? (iii) Which is the major physiological function of IGF-II/CI-M6P receptors in the CNS, sorting M6P-containing molecules or developing transmembrane signals for IGF-II? (iv) What is the major biological function in which IGF-II/CI-M6P receptors participate in the CNS? As one of the first steps in addressing these issues, it is important to precisely evaluate the cellular distribution of IGF-II/CI-M6P receptors and their subcellular localization in the $\mathrm{CNS}$, and to determine the major cellular targets of IGF-II in the CNS. It is also important to determine whether the IGF-II/CI-M6P receptors in the CNS cells can respond to exogenously administered IGF-II.

To examine the cellular and subcellular localization of IGF-II/CI-M6P receptors, radioisotope-labeled IGF-II in the form of $\left[{ }^{125} \mathrm{I}\right] \mathrm{IGF}-\mathrm{II}$ and antibodies raised against IGF-II/CIM6P receptors can now be used. With regard to the nervous system in particular, there have been a limited number of studies using immunohistochemical techniques that have morphologically shown the exact cellular and subcellular localization of IGF-II/CI-M6P receptors. The functional binding of IGF-II to targets may be modified by IGF-I receptors [7] and IGF binding proteins (IGFBPs) [4, 5, 10]. In addition, as mentioned above, the IGF-II receptor is identical to the CI-M6P receptor [18], which mediates the sorting of M6P-containing lysosomal enzymes and ligands to lysosomes [17]. Therefore, IGF-II-binding is thought to be indicative of only part of all the expression patterns of the IGF-II/CI-M6P receptors. In the present study, using immunohistochemistry with a specific antibody raised against IGF-II/CI-M6P receptors, we showed that these receptors are distributed throughout the CNS, but their intense immunoreactivity is almost fully restricted to middleto large-sized neurons. Although the receptors are mostly localized in the cytoplasm, not in the plasma membrane, by immuno-EM of cultured neurons they can be observed on the neuronal cell surface in response to exogenously administered IGF-II. This is the first report to demonstrate surface expression of IGF-II/CI-M6P receptors in neurons particularly by immuno-scanning EM.

\section{Materials and Methods}

\section{Tissue preparations}

Fourteen 12- to 17-week-old male $\mathrm{BALB} / \mathrm{c}$ mice weighing 25-30 grams (Japan SLC) were used for the present study. The animals were deeply anesthetized with 50 $\mathrm{mg} / \mathrm{kg}$ (body weight) sodium pentobarbital and transcardially perfused, initially with $0.9 \%$ sodium chloride $(\mathrm{NaCl})$ solution containing $4 \mathrm{U} / \mathrm{ml}$ heparin sodium and subsequently with a fixative containing 4\% paraformaldehyde (PFA) and $0.1 \%$ glutaraldehyde (GA) in $0.1 \mathrm{M}$ cacodylate buffer (CB, $\mathrm{pH}$ 7.4). The brain and spinal cord were quickly removed after the perfusion and immersed in a post-fixative containing $2 \%$ PFA and $0.05 \% \mathrm{GA}$ in $0.1 \mathrm{M} \mathrm{CB}(\mathrm{pH} 7.4)$ overnight at $4^{\circ} \mathrm{C}$.

Some tissue samples were transferred into phosphate buffered saline (PBS) and cut into $50 \mu \mathrm{m}$ thick sections using a microslicer (DTK-3000, Dosaka EM). The sections were collected in PBS in a free-floating state. The remaining samples were transferred into a graded series of sucrose solutions in the order of $10,15,20$, and $30 \%$, frozen with dry ice in acetone, and cut into $10 \mu \mathrm{m}$ thick sections with a cryostat (Bright Instrument).

\section{Animals}

The present study was approved by the Animal Research Committee of Kawasaki Medical School, and the experimental animals were treated according to the Guide for the Care and Use of Laboratory Animals of Kawasaki Medical School. These experiments were also conducted in compliance with the Society for Neuroscience Policy on the Use of Animals in Neuroscience Research.

\section{Immunohistochemistry for tissue sections}

The primary antibody used for the present study was a rabbit polyclonal antibody raised against the whole length of IGF-II/CI-M6P receptors purified from membrane fractions of adult rat liver on a M6P affinity column, according to a procedure described elsewhere [24]. This antibody was a generous gift from Dr. M. Himeno (Kyushu University, Japan).

The free-floating sections were incubated with the antiIGF-II/Cl-M6P receptor antibody diluted at 1:2000 with PBS containing $0.3 \%$ Triton $\mathrm{X}-100$ for three days at $4{ }^{\circ} \mathrm{C}$. Thereafter they were incubated with biotinylated goat antirabbit IgGs (1:200, Vector Laboratories). Subsequently, they were reacted with the avidin-biotin-horseradish peroxidase complex (Vectastain Elite ABC Kit, Vector), according to the manufacture's protocol, and the peroxidase activity was visualized by incubation with $0.05 \%$ 3,3'-diaminobenzidine (DAB).

The frozen sections were incubated with the primary antibody at the same concentration as described above overnight at $4^{\circ} \mathrm{C}$, and then were processed similarly, using the procedure for the free-floating sections.

In parallel, the tissue sections were treated with nonimmune rabbit IgGs with omission of the anti-IGF-II/CI- 
M6P receptor antibody.

\section{Immuno-electron microscopy for tissue sections}

The free-floating sections were treated as described above except that Triton X-100 was not added to the incubation solution including the anti-IGF-II/CI-M6P receptor antibody. Parallel sections treated with omission of the primary antibody were used as a negative control. After development of peroxidase activity, the sections were postfixed with $0.1 \mathrm{M} \mathrm{CB}$ containing $2 \%$ osmium tetroxide $\left(\mathrm{OsO}_{4}\right)$ for $40 \mathrm{~min}$ at room temperature (RT), dehydrated, and then polymerized with Epon 812 (TAAB) according to standard procedures. The polymerized samples were cut into ultra-thin sections, stained with $2 \%$ uranyl acetate for $10 \mathrm{~min}$ at RT, and subsequently examined with a Hitachi H-7100 electron microscope (Hitachi) with an accelerating voltage at $75 \mathrm{kV}$.

\section{Primary cultures of cortical neurons}

Our techniques for obtaining and culturing primary neurons from embryonic mouse brain have previously been described in detail [12]. After characterization to show that more than $95 \%$ of the cultured cells from the septal, hippocampal and cortical areas are neurons in a serum-free medium $[12,15]$, our neurons have successfully been used for several studies [14, 31].

\section{Immunofluorescence for cultured neurons}

For this study, the primary neurons were grown on glass coverslips coated with $1 \mathrm{mg} / \mathrm{ml}$ poly-L-lysine (PLL, Sigma) in the culture medium in plastic dishes. Two days after initial plating, the cultured neurons were processed for immunofluorescence. Two procedures were used to detect IGF-II/CI-M6P receptors in the neurons treated with IGF-II: (i) The cultured neurons were rinsed with warm $\left(37^{\circ} \mathrm{C}\right) \mathrm{PBS}$ and fixed with $4 \%$ PFA in PBS for 15 min at RT after having been treated with $10 \mathrm{ng} / \mathrm{ml}$ IGF-II (human recombinant, Pepro Tech) in the culture medium for $15 \mathrm{~min}$, and 1 and 3 hr at $37^{\circ} \mathrm{C}$ in a $\mathrm{CO}_{2}$ incubator. The fixed neurons were then incubated with the anti-IGF-II/Cl-M6P receptor antibody diluted at 1:100 with PBS overnight at $4^{\circ} \mathrm{C}$; (ii) The cultured neurons were rinsed with warm PBS and fixed with 4\% PFA in PBS for $15 \mathrm{~min}$ at RT after having been treated concurrently with the IGF-II and anti-IGF-II/CI-M6P receptor antibody at the same concentrations as above in the culture medium for $15 \mathrm{~min}$, and 1 and $3 \mathrm{hr}$ at $37^{\circ} \mathrm{C}$ in a $\mathrm{CO}_{2}$ incubator. Following these two procedures, they were incubated with FITC-conjugated goat anti-rabbit IgGs (1:100, Cappel), and were then partly counterstained with $0.01 \%$ Evans blue. The fixed neurons were treated with non-immune rabbit IgGs in parallel.

With the first procedure, the neurons were treated with the anti-IGF-II/CI-M6P receptor antibody after fixation. The antibody is generally expected to not only recognize IGF-II/ CI-M6P receptors on the cell surface but to also passively permeate into the cells to be bound to IGF-II/CI-M6P receptors localized within the cells. Therefore, with the first pro- cedure, positive immunofluorescence can also identify IGFII/CI-M6P receptors that are involved in sorting newly synthesized lysosomal enzymes from Golgi reticulum to lysosomes or those that are in their biosynthesis pathway, in addition to the IGF-II/CI-M6P receptors that have once been expressed on the cell surface because of their interaction with IGF-II. With the second procedure, the anti-IGFII/CI-M6P receptor antibody was added to living neurons concurrently with IGF-II before fixation. This technique is usually employed for studying endocytosis and internalization of surface receptors for cytokines and growth factors in living cells [9]. The antibody is generally expected to initially recognize IGF-II/CI-M6P receptors only expressed in the cell surface, although it may then be internalized into the cells together with the receptor-IGF-II complex. Therefore, with the second procedure, positive immunofluorescence can only identify IGF-II/CI-M6P receptors that have once been expressed on the cell surface possibly for the development of transmembrane IGF-II signals.

\section{Immuno-electron microscopy for cultured neurons}

The primary cultured neurons were processed for immuno-electron microscopic study two days after initial plating on plastic coverslips coated with $10 \mu \mathrm{g} / \mathrm{ml}$ PLL. Using immuno-scanning EM (immuno-SEM), two procedures were employed to detect IGF-II/CI-M6P receptors in the neurons treated with IGF-II. These two procedures were respectively identical to (i) and (ii) in our methods for the immunofluorescence of cultured neurons mentioned above, except that as a fixative, $\mathrm{CB}(\mathrm{pH} 7.4)$ containing $4 \%$ PFA and $0.1 \%$ GA was used. Following these procedures, the neurons were respectively incubated with protein A-gold colloidal particles (particle diameter, $20 \mathrm{~nm}$; E-Y $\mathrm{Lab}$ ) suspended in five volumes of PBS at RT for $1 \mathrm{hr}$. After rinsing several times with $\mathrm{PBS}$, the neurons were re-fixed with $2 \%$ GA for $15 \mathrm{~min}$ and with $1 \% \mathrm{OsO}_{4}$ for $1 \mathrm{hr}$. For surface conductivity, they were stained with $2 \%$ tannic acid (Merck) for $2 \mathrm{hr}$ and with $1 \% \mathrm{OsO}_{4}$ for $1 \mathrm{hr}$. They were then dehydrated with a graded ethanol series, which was later replaced with $t$-butyl alcohol, dried by freeze-drying, coated with carbon, and examined with a field emission scanning electron microscope (JSM-6340F, JEOL) with an accelerating voltage at $15 \mathrm{kV}$.

The rationales behind these two procedures were similar to those behind the two in our immunofluorescence study. With the first procedure, the neurons were treated with the anti-IGF-II/CI-M6P receptor antibody after fixation. This antibody is generally expected to not only recognize IGF-II/CI-M6P receptors on the cell surface but to also passively permeate into the cells to be bound to IGF-II/CIM6P receptors localizing within the cells. With the second procedure, the anti-IGF-II/CI-M6P receptor antibody was added to living neurons concurrently with IGF-II before fixation. The antibody is generally expected to initially bind to IGF-II/CI-M6P receptors only expressed on the cell surface. Our second procedure with immuno-SEM was a modification of the method reported by Yamada et al. [30], who add- 
ed antibodies before fixation to observe the cell surface localization of a certain molecule. With immuno-SEM, gold particles tagged on the cell surface can generally be seen, but gold particles inside the cells are not visible. Therefore, irrespective of the two procedures, the gold particles visible on the cell surface identify the number of IGF-II/CI-M6P receptors which are present on the cell surface in response to the IGF-II treatment but which have yet to be internalized. The receptors internalized from the cell surface as well as those involved in the sorting within the cells are invisible. By contrast, fluorescent dyes both on the cell surface and within cells can generally be seen under a fluorescence microscope. Therefore, with the second procedure of our immunofluorescence study, the immunoreactivity identifies both the number of IGF-II/CI-M6P receptors present on the cell surface and within the cells following internalization.

For immuno-transmission EM (immuno-TEM), the primary cultured neurons were treated with both IGF-II and anti-IGF-II/CI-M6P receptor antibody in the culture medium, fixed, incubated with the protein A-gold colloidal particle suspension, rinsed, re-fixed, and dehydrated by the same procedures used for the SEM study with the exception that the diameter of the protein A-gold particles was 5 nm. Next, the neurons were polymerized with Epon 812 (TAAB). The polymerized samples were cut into ultra-thin sections, stained with $2 \%$ uranyl acetate for $20 \mathrm{~min}$ at RT, and examined with an electron microscope (H-7100, Hitachi) with an accelerating voltage at $75 \mathrm{kV}$.

\section{Western blot analysis of brain tissues and primary cortical neurons}

For our Western blot analysis, tissue samples were taken from the cerebral cortices of three adult male mice, and individually homogenized in five volumes of a buffer containing $10 \mathrm{mM}$ Tris- $\mathrm{HCl}$ (pH 7.4), $25 \mathrm{mM} \mathrm{NaCl}, 50 \mathrm{mM}$ ethylene diamine tetraacetic acid (EDTA), 2\% sodium dodecyl sulfate (SDS), and a protease inhibitor cocktail (Complete Mini, No. 1836153; Roche). The homogenates were centrifuged at $15,000 \times g$ for $20 \mathrm{~min}$ at $4^{\circ} \mathrm{C}$. For each sample, $20 \mu \mathrm{g}$ of protein in the supernatant was electrophoresed on a $5-20 \%$ polyacrylamide-SDS gel, transferred electrophoretically onto a polyvinylidene difluoride (PVDF) membrane (Millipore), and further processed for immunostaining. The membrane was blocked with $1.5 \%$ blocking reagent (Roche) for $1 \mathrm{hr}$ at RT, and subsequently incubated with the anti-IGF-II/CI-M6P receptor antibody diluted at 1:4000 with the blocking reagent overnight at $4{ }^{\circ} \mathrm{C}$, with a horseradish peroxidase-conjugated secondary antibody (Amersham), and with the ECL plus Western Blotting Detection System (RPN2132, Amersham). The blocking peptide (sc-14414P; Santa Cruz), which is a peptide mapping near the carboxy terminus of mouse IGF-IIR used for generating the IGF-IIR polyclonal antibody (M-14, sc-14414; Santa Cruz), was employed to partly preabsorb the IGF-II/CI-M6P receptor polyclonal antibody raised against the whole length of IGF-II/CI-M6P receptors.
The primary cortical neurons were grown in plastic dishes coated with $10 \mu \mathrm{g} / \mathrm{ml}$ PLL. Two days after initial plating, $10 \mathrm{ng} / \mathrm{ml}$ IGF-II was added to the cultures. The treated neurons were collected before, 15 and $30 \mathrm{~min}$, and 1 and $3 \mathrm{hr}$ after the addition of IGF-II. The collected cells were homogenized in a buffer composed of $20 \mathrm{mM}$ Tris- $\mathrm{HCl}(\mathrm{pH} 7.4)$, $150 \mathrm{mM} \mathrm{NaCl}, 1 \mathrm{mM}$ EDTA, and several protease inhibitors previously described in detail [15], and centrifuged at $700 \times g$ for $10 \mathrm{~min}$ at $4^{\circ} \mathrm{C}$. The supernatant was recentrifuged at $32,000 \times g$ for $35 \mathrm{~min}$ at $4^{\circ} \mathrm{C}$. As previously reported $[15,16]$, the final pellet composed of membrane fractions containing plasma membranes was lysed by boiling for $3 \mathrm{~min}$ in $10 \mathrm{mM}$ phosphate buffer ( $\mathrm{pH}$ 6.8) containing $28.6 \mathrm{mM}$ dithiothreitol (Wako) and 5.7\% SDS. For each sample, $20 \mu \mathrm{g}$ of protein in the lysate was further processed for Western blot analysis. This was identical to the procedure for the tissue samples.

\section{Results}

\section{Light-microscopic findings of IGF-II/CI-M6P receptor immunoreactivity in the adult mouse CNS}

Numerous middle- to large-sized IGF-II/CI-M6P receptor-immunoreactive cells were observed throughout the CNS and their distribution matched neuronal localization (Fig. 1A). Most of the positive cells were thought to be neurons on the basis of their morphological features as well as their distribution patterns. The distribution of the IGF-II/CIM6P receptor immunoreactivity was determined by examining a series of coronal sections obtained from a whole mouse brain and cervical spinal cord (Fig. 3). The middle- to largesized neuronal cells that revealed intense IGF-II/CI-M6P receptor immunoreactivity were largely localized in the fifth layer of the cerebral cortex (Fig. 1B), locus ceruleus, medial septal nucleus (Fig. 1A, C), nucleus of the diagonal band of Broca (Fig. 1A), medial habenular nucleus, substantia nigra, red nucleus, median eminence, Purkinje cell layer, and ventral horn of the spinal cord. Neuronal cells in the CA1, CA2 and CA3 pyramidal cell layers of the hippocampus were also intensely labeled with the anti-IGF-II/CI-M6P receptor antibody (Fig. 2A, B), whereas granule cells in the hippocampus were partly and slightly stained (Fig. 2A). The distribution of IGF-IIR/CI-MPR immunoreactivity determined in the present study is schematically summarized in Figure 3.

At a higher magnification, antigens immunoreactive for the IGF-II/CI-M6P receptors were found in the cytoplasm and processes of neuronal cells with a granular appearance, but not in cytoplasmic membranes throughout the CNS (Fig. $1 \mathrm{~B}, \mathrm{C})$. We found no differences between the staining patterns obtained from the frozen and microslicer sections (Fig. 1B, C). In the gray matter and nuclei where neurons are abundant, neurons were almost exclusively labeled with the IGF-II/CI-M6P receptor antibody. In the cerebral white matter, only a small number of glial cells were weakly to moderately stained with the IGF-II/CI-M6P receptor antibody (Fig. 1Da, b). No IGF-II/CI-M6P receptor immunoreactivity was found when the primary antibody was replaced 

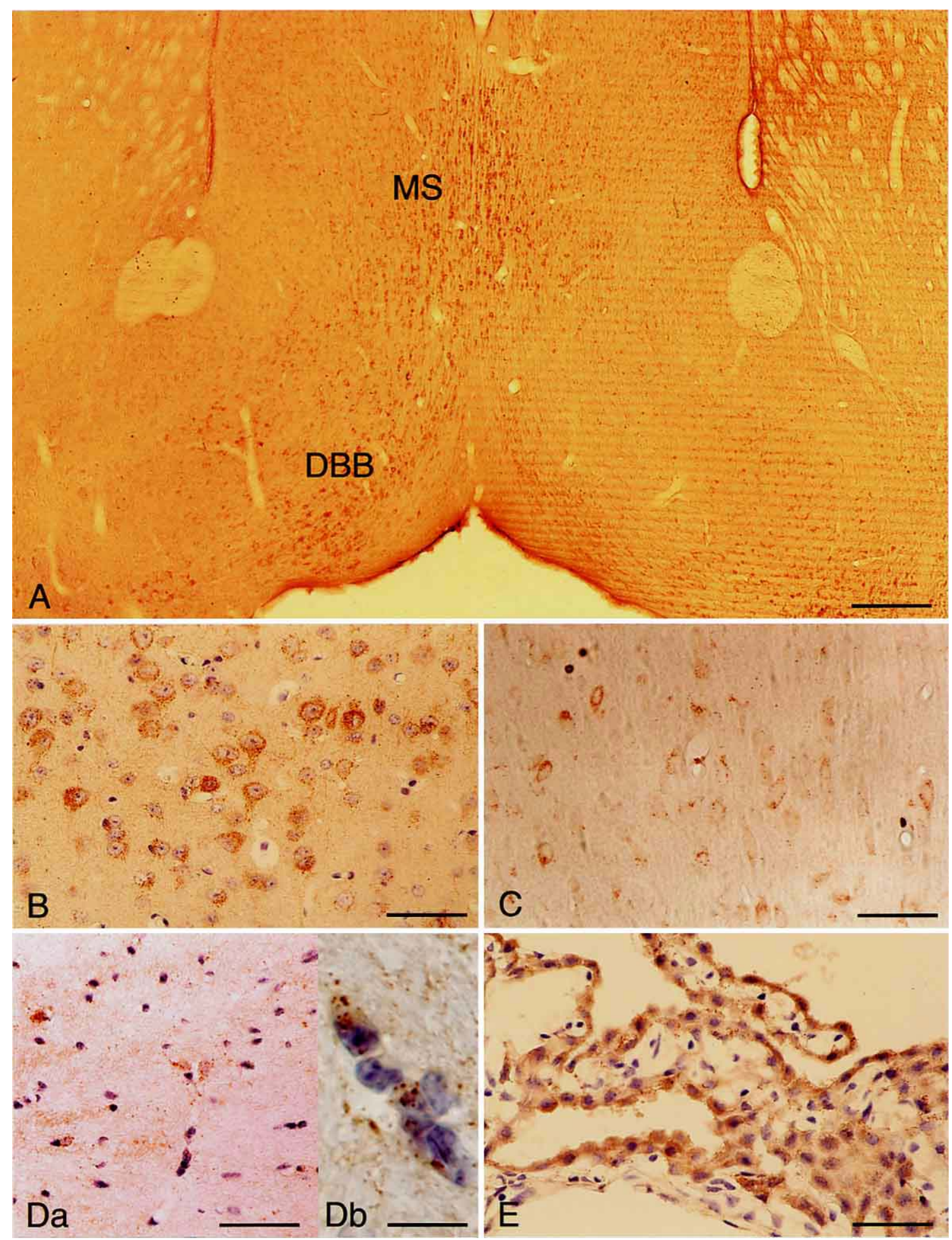

Fig. 1. Immunohistochemical distribution of insulin-like growth factor (IGF)-II/cation-independent mannose-6-phosphate (CI-M6P) receptors in the adult mouse brain. A: A coronal section including the medial septal nuclei (MS) and the nuclei of the diagonal band of Broca (DBB) shows that the immunoreactivity of the IGF-II/CI-M6P receptors matches neuronal distribution. Bar $=350 \mu \mathrm{m}$. B: Positively-labeled neurons in a granular pattern are seen in the cerebral cortex (frozen section). Bar=50 $\mu \mathrm{m}$. C: Positively-labeled neurons in a granular pattern are seen in the medial septum (floating section). Bar=50 $\mu \mathrm{m}$. D: a. A small number of glial cells show immunoreactivity for the IGF-II/CI-M6P receptors in the white matter of the cerebral hemisphere in a frozen section. Bar $=50 \mu \mathrm{m}$. b. At higher magnification, immunoreactive granules are seen in the cytoplasm of glial cells in the cerebral white matter (frozen section). Bar=10 $\mu \mathrm{m}$. E: Epithelial cells of the choroid plexus are strongly positive for the IGF-II/CI-M6P receptors, while the mesenchymal tissue under the epithelial cell layer is negative. Bar $=50 \mu$ m. Nuclei were counterstained with hematoxylin after immunostaining $(\mathbf{B}, \mathbf{D}, \mathbf{E})$. 


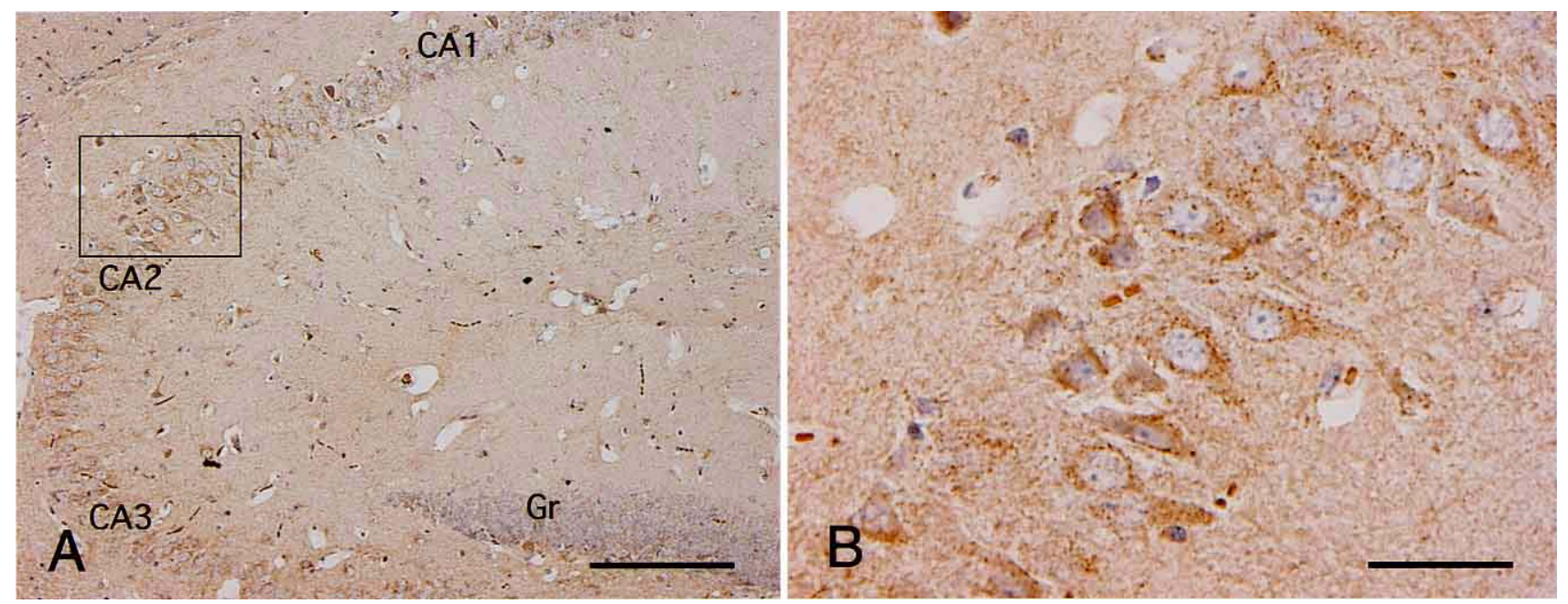

Fig. 2. Immunohistochemistry of insulin-like growth factor (IGF)-II/cation-independent mannose-6-phosphate (CI-M6P) receptors in the hippocampus of the adult mouse brain. A: Neurons of the pyramidal cell layer in the hippocampus are mostly positive for the IGF-II/CI-M6P receptors. The labeling shows no significant differences among neurons in the CA1, CA2 and CA3 pyramidal cell layers. Neurons in the granule cell layers (Gr) are partly and slightly stained. Bar=200 $\mu \mathrm{m}$. B: A higher magnification of the area indicated with a rectangle in panel A shows the labeled neurons with a granular appearance in the pyramidal cell layer. Bar $=50 \mu \mathrm{m}$. Nuclei were counterstained with hematoxylin after immunostaining (A, B).

with non-immune rabbit IgGs (data not shown).

Epithelial cells of the choroid plexus were strongly positive for IGF-II/CI-M6P receptors, showing a similar granular appearance in the cytoplasm, while the mesenchymal tissue in the choroid plexus was negative (Fig. 1E). The number of positive granules in each epithelial cell seemed to be larger than that in each neuronal cell.

\section{Immuno-electron microscopic findings of IGF-II/CI-M6P receptor immunoreactivity in the adult mouse CNS}

Subcellular localization of IGF-II/CI-M6P receptor immunoreactivity was examined by immuno-EM. IGF-II/CIM6P receptor immunoreactivity was recognized within the lysosome- or endosome-like structures of neurons (Fig. 4), but not in their plasma membranes.

\section{IGF-II/CI-M6P receptor immunofluorescence in primary cortical neurons treated with IGF-II}

To detect IGF-II/CI-M6P receptors in the primary cortical neurons treated with IGF-II, two immunocytochemical procedures were employed. With the first procedure, the neurons were treated with the anti-IGF-II/CI-M6P receptor antibody after fixation. In the present study, we observed intense IGF-II/CI-M6P receptor immunoreactivity in the cell bodies and neurites with a granular appearance (Fig. 5A). With this technique, however, the immunoreactivity for the receptors that had once been expressed on the cell surface and then internalized into the cells could not be distinguished from either the immunoreactivity for those involved in such sorting within the cells or that for those in their biosynthesis pathway. The density of the immunoreactive granules obtained by this procedure (Fig. 5A) was much higher than that by the second procedure (Fig. 5B). The IGF-II treatment induced no changes in the immunoreactive density or intensity in each neuronal cell. Therefore, these findings indicated that most of the immunoreactive granules shown in Figure 5A originated from IGF-II/CI-M6P receptors involved in sorting numerous lysosomal enzymes within the neurons but not in developing transmembrane IGF-II signals. The number of receptors involved in the sorting was likely to be greater than that involved in the development of IGF-II signals.

With the second procedure, the anti-IGF-II/CI-M6P receptor antibody was added to living neurons concurrently with IGF-II before fixation. In the present study, several IGF-II/CI-M6P receptor-immunoreactive granules were observed (Fig. 5B). According to the rationale behind this second method, we had expected to observe only the surface existence of the receptors. Contrary to our expectation, not many of the immunoreactive granules existed at the cell margin (arrows in Fig. 5B). Most of them seemed to be localized within the cells (Fig. 5B), although they were thought to be derived from the IGF-II/CI-M6P receptors internalized from the cell surface or to have resulted from non-specific endocytosis of the antibody alone. However, the possibility could not be excluded that numerous, weakly immunoreactive granules were present on the cell surface. Therefore, immuno-EM was required for a more precise examination of subcellular localization. Furthermore, with the second procedure, no immunoreactivity of the neurons was observed without the addition of IGF-II (data not shown). This was also noted in our immuno-SEM (Fig. 7A) and -TEM (data not shown) studies. The immunoreactivity actually became positive with the addition of IGF-II. The density of the immunoreactive granules was highest at $1 \mathrm{hr}$ after the addition of IGF-II (Fig. 5B). These findings indicated that 

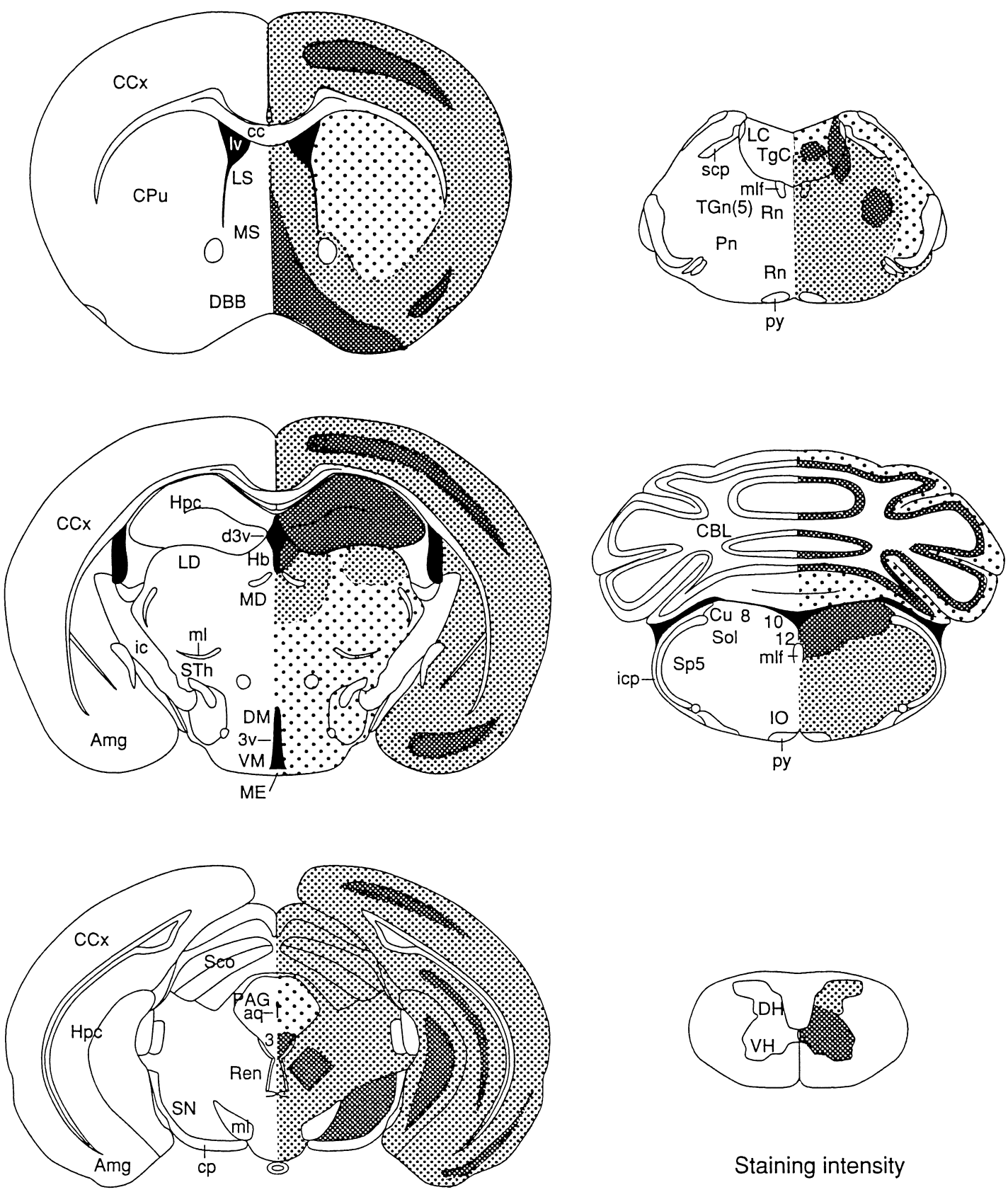

Staining intensity

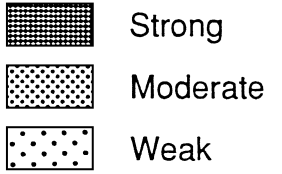

Fig. 3. Schematic summary of the distribution of the immunoreactivity for insulin-like growth factor (IGF)-II/cation-independent mannose-6phosphate (CI-M6P) receptors in the adult mouse CNS. The distribution of the IGF-II/CI-M6P receptor immunoreactivity determined by examining a series of coronal sections obtained from a whole mouse brain and spinal cord is schematically summarized.

Abbreviations: 3, oculomotor nucleus; 3v, 3rd ventricle; 8, vestibular nucleus; 10, dorsal motor nucleus of vagus; 12, hypoglossal nucleus; Amg, amygdaloid nucleus; aq, aqueduct (Sylvius); CBL, cerebellum; cc, corpus callosum; cp, cerebral peduncle; $\mathrm{CPu}$, caudate putamen (striatum); $\mathrm{CCx}$, cerebral cortex; $\mathrm{Cu}$, cuneate nucleus; d3v, dorsal 3rd ventricle; $\mathrm{DH}$, dorsal horn of the spinal cord; DBB, diagonal band of Broca; DM, dorsomedial hypothalamic nucleus; $\mathrm{Hb}$, habenular nucleus; Hpc, hippocampus; ic, internal capsule; icp, inferior cerebellar peduncle; IO, inferior olive; LC, loculs ceruleus; LD, laterodorsal thalamic nucleus; LS, lateral septal nucleus; lv, lateral ventricle; MD, mediodorsal thalamic nucleus; ME, median eminence; $\mathrm{ml}$, medial leminiscus; mlf, medial longitudinal fasciculus; MS, medial septal nucleus; PAG, periaqueductal gray matter; Pn, pontine reticular nucleus; py, pyramidal tract; Ren, red nucleus; Rn, raphe nucleus; Sco, superior colliculus; scp, superior cerebellar peduncle; SN, substantia nigra; Sol, solitary tract nucleus; Sp5, spinal trigeminal nucleus; STh, subthalamic nucleus; TgC, dorsal tegmental nucleus; TGn(5), motor trigeminal nucleus; VH, ventral horn of the spinal cord; VM, ventromedial hypothalamic nucleus. 


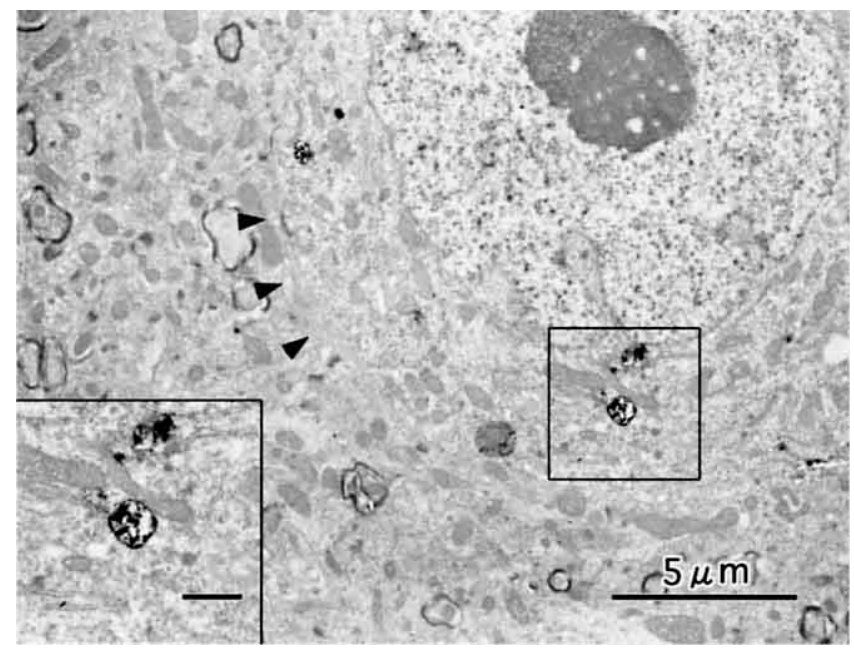

Fig. 4. Immuno-transmission electron microscopy of insulin-like growth factor (IGF)-II/cation-independent mannose-6-phosphate (CI-M6P) receptors in the adult mouse brain. IGF-II/CI-M6P receptor immunoreactivity is recognized within the lysosome/ endosome-like structures (in the square), but not in the cytoplasmic membrane (arrowheads). Bar=5 $\mu \mathrm{m}$. A higher magnification of the area within the square is shown in the inset. Bar=1 $\mu \mathrm{m}$.
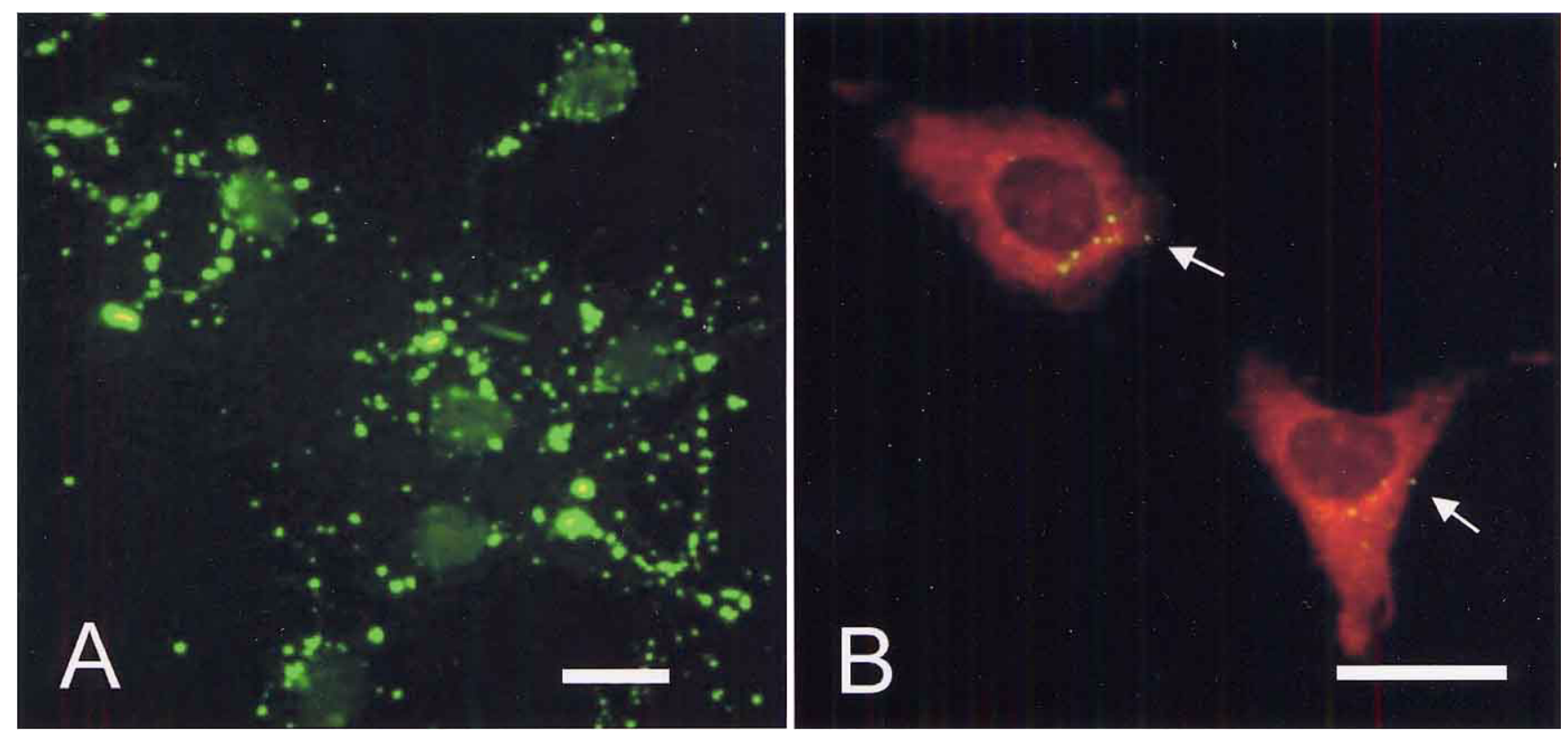

Fig. 5. Immunofluorescence of insulin-like growth factor (IGF)-II/cation-independent mannose-6-phosphate (CI-M6P) receptors in primary cortical neurons treated with IGF-II. To detect IGF-II/CI-M6P receptors in the primary cortical neurons treated with IGF-II, the following two immunocytochemical procedures were employed. A: With the first procedure (see Materials and Methods), the neurons were treated with the anti-IGF-II/CI-M6P receptor antibody after fixation. The receptor antibody was expected to recognize the receptors localized within the neurons as well as those present on the cell surface. In the present study with this procedure, intense IGF-II/CI-M6P receptor immunoreactivity (green fluorescence) was seen in the cell bodies and neurites with a granular appearance. The IGF-II treatment induced no changes in the immunoreactive density or intensity in each neuronal cell. Panel A shows the staining of neurons fixed $1 \mathrm{hr}$ after the addition of IGF-II. Bar=25 $\mu \mathrm{m}$. B: With the second procedure (see Materials and Methods), the anti-IGF-II/CI-M6P receptor antibody was added to living neurons concurrently with IGF-II treatment before fixation. The receptor antibody was expected to initially recognize the receptors expressed only on the cell surface. In the present study with this procedure, several IGF-II/CI-M6P receptor-immunoreactive granules (green fluorescence) were observed. Contrary to our expectation, most of them seemed to be localized within the cells and not many existed at the cell margin, although a few possibly appeared to lie on the cell surface (arrows). The density of the immunoreactive granules was highest $1 \mathrm{hr}$ after the addition of IGF-II, but none was observed without the addition of IGF-II. Panel B shows the staining of neurons fixed $1 \mathrm{hr}$ after the addition of both IGF-II and the antibody. The neurons were counterstained with $0.01 \%$ Evans blue (red fluorescence). Bar $=25 \mu \mathrm{m}$.

most of the immunoreactive granules shown with our second procedure (e.g. Fig. 5B) originated from IGF-II/CI-M6P receptors involved in developing transmembrane IGF-II signals by their surface expression. Therefore, it was unlikely that the antibody alone entered the cells via non-specific endocytosis. If the antibody had non-specifically been endo- 


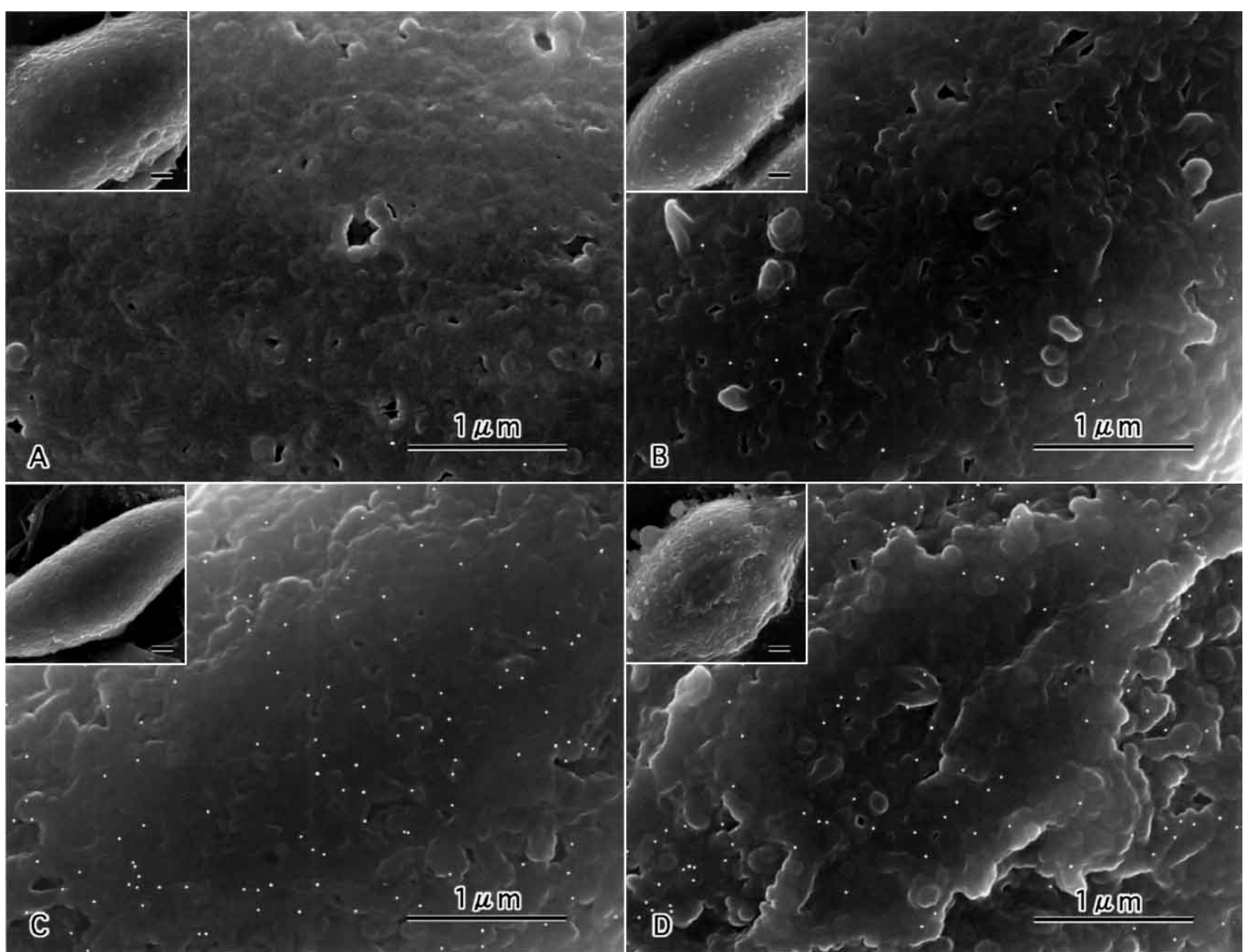

Fig. 6. Immuno-scanning electron microscopy (SEM) of insulin-like growth factor (IGF)-II/cation-independent mannose-6-phosphate (CI-M6P) receptors in primary cortical neurons with the first procedure. The neurons were treated with the anti-IGF-II/CI-M6P receptor antibody after fixation. With the addition of IGF-II, gold particles were tagged on the cell surface of the neurons. The labeling density of gold particles on the cell surface was highest at $1 \mathrm{hr}$ after the addition of IGF-II (Panels A: before; B: $15 \mathrm{~min}, \mathbf{C}: 1 \mathrm{hr}, \mathbf{D}: 3 \mathrm{hr}$ after the addition). A few gold particles on the cell surface are seen without the addition of IGF-II (Panel A), and several are still tagged on the cell surface $3 \mathrm{hr}$ after the addition (Panel D). Each panel is a higher magnification of part of the field in each inset. Bars $=1 \mu \mathrm{m}$.

cytosed into the cells and then bound to IGF-II/CI-M6P receptors involved only in the sorting inside the cells, the immunoreactive granules would have been observed even without the addition of IGF-II.

No immunoreactivity for IGF-II/CI-M6P receptors was found in the primary neurons when the primary antibody was replaced with non-immune rabbit IgGs (data not shown).

\section{Immuno-SEM findings in primary cortical neurons treated with IGF-II}

Because of the limitations of immunofluorescence microscopy with regards to sensitivity and resolution in demonstrating the receptors expressed on the cell surface as mentioned above, immuno-EM was employed. Two immuno-electron microscopical procedures were employed and their rationales were similar to those behind the two procedures in our immunofluorescence study. As noted in Materials and Methods, irrespective of the procedure, the gold particles visible on the cell surface generally identify the number of IGF-II/CI-M6P receptors which are present in the cell surface but which have yet to be internalized.

In the present study, the gold particles were actually found to be tagged on the cell surface of the neurons with both the first procedure (Fig. 6) and the second procedure (Fig. 7). Regardless of the procedure, the density of the gold particles tagged on the neuronal surface was highest at $1 \mathrm{hr}$ after the addition of IGF-II (Figs. 6A, 7A: before; 6B, 7B: 15 $\min , 6 \mathrm{C}, 7 \mathrm{C}: 1 \mathrm{hr}, 6 \mathrm{D}, 7 \mathrm{D}: 3 \mathrm{hr}$ after the addition). This finding indicated that IGF-II induced IGF-II/CI-M6P receptor expression on the cell surface of the primary cortical neurons and that the interaction of IGF-II with the receptors was not blocked by the addition of the receptor antibody in the second procedure. However, the second procedure more 


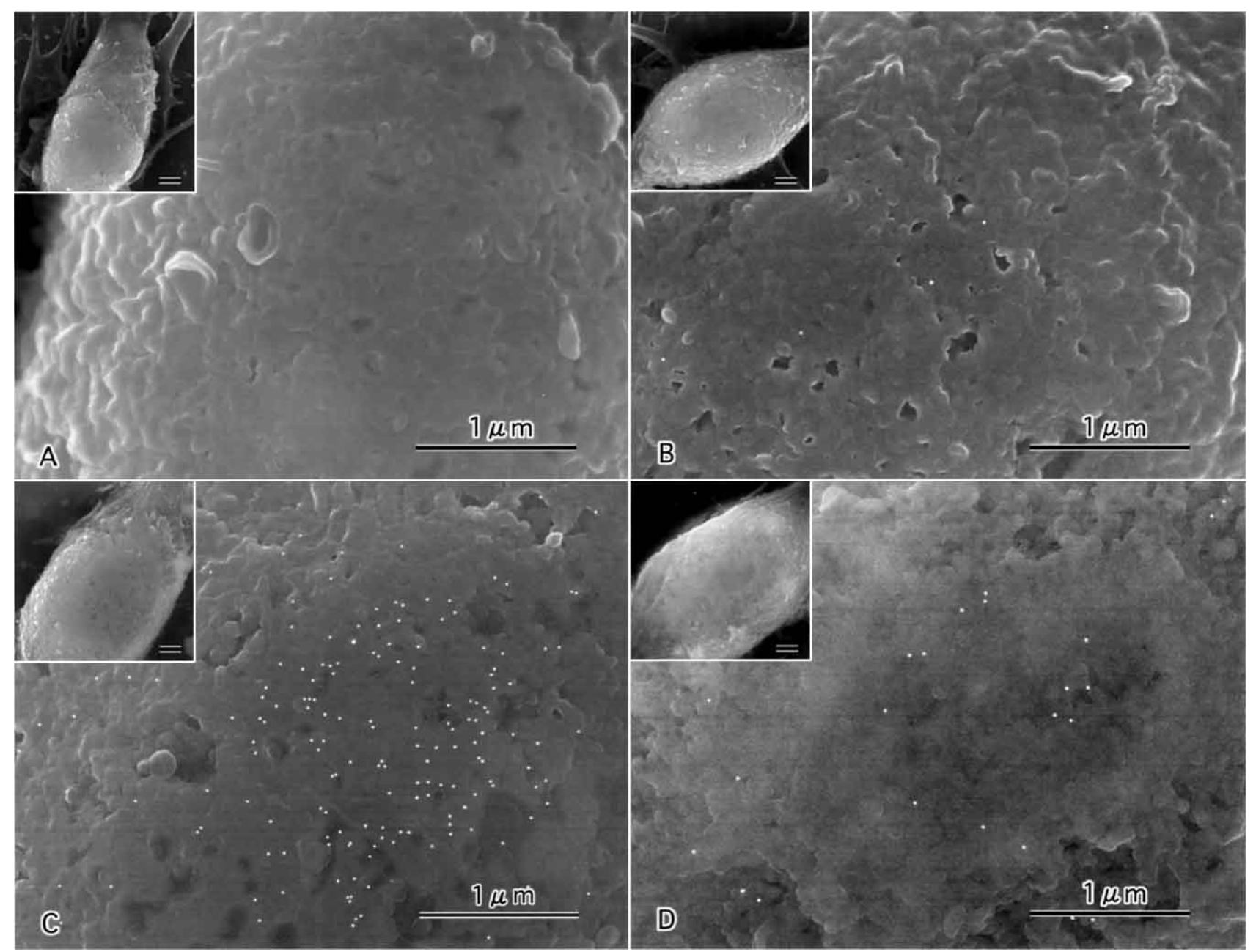

Fig. 7. Immuno-scanning electron microscopy (SEM) of insulin-like growth factor (IGF)-II/cation-independent mannose-6-phosphate (CI-M6P) receptors in primary cortical neurons with the second procedure. The anti-IGF-II/CI-M6P receptor antibody was added to living neurons concurrently with IGF-II treatment before fixation. With the addition of IGF-II, gold particles were tagged on the cell surface of the neurons. Similar to the data with the first procedure, the labeling density of gold particles on the cell surface was highest at $1 \mathrm{hr}$ after the addition of IGF-II (Panels A: before; B: $15 \mathrm{~min}, \mathbf{C}: 1 \mathrm{hr}, \mathbf{D}: 3 \mathrm{hr}$ after the addition). Compared to the data with the first procedure, however, no gold particles are seen on the cell surface without the addition of IGF-II (Panel A), and a smaller number of particles are tagged on the cell surface $3 \mathrm{hr}$ after the addition (Panel D). Each panel is a higher magnification of part of the field in each inset. Bars $=1 \mu \mathrm{m}$.

successfully demonstrated a remarkable increase in the receptors expressed on the cell surface upon exposure to IGFII (compare Fig. 6 with Fig. 7). This may have been because the receptor antibody more easily recognized the receptors in unfixed than fixed neurons, leading us to observe that the first procedure produced more non-specific binding of the antibody to the neurons, and may also have been because the receptor antibody as well as IGF-II directly acted on the neurons to induce IGF-II/CI-M6P receptor expression on their cell surface. Certainly the latter possibility can be ruled out because no labeling on the neuronal surface was observed when IGF-II was omitted from the second procedure (data not shown).

No labeling on the cell surface membrane was detected when the primary antibody was replaced with non-immune rabbit IgGs (data not shown).

\section{Immuno-TEM findings in primary cortical neurons treated with IGF-II}

For our immuno-TEM study, the anti-IGF-II/CI-M6P receptor antibody was added to living neurons concurrently with IGF-II before fixation, based on the advantage in demonstrating specific receptors for exogenous IGF-II.

In the present study, gold particles were mostly seen in the cell surface of the neurons (Fig. 8). Similarly, the labeling density of gold particles on the cell surface was highest at $1 \mathrm{hr}$ after the addition of IGF-II. This finding was consistent with the result obtained with immuno-SEM.

\section{Western blot analysis of IGF-II/CI-M6P receptors in brain tissues and primary neurons}

With the IGF-II/CI-M6P receptor antibody provided by Dr. M. Himeno, Western blot analysis was performed on 


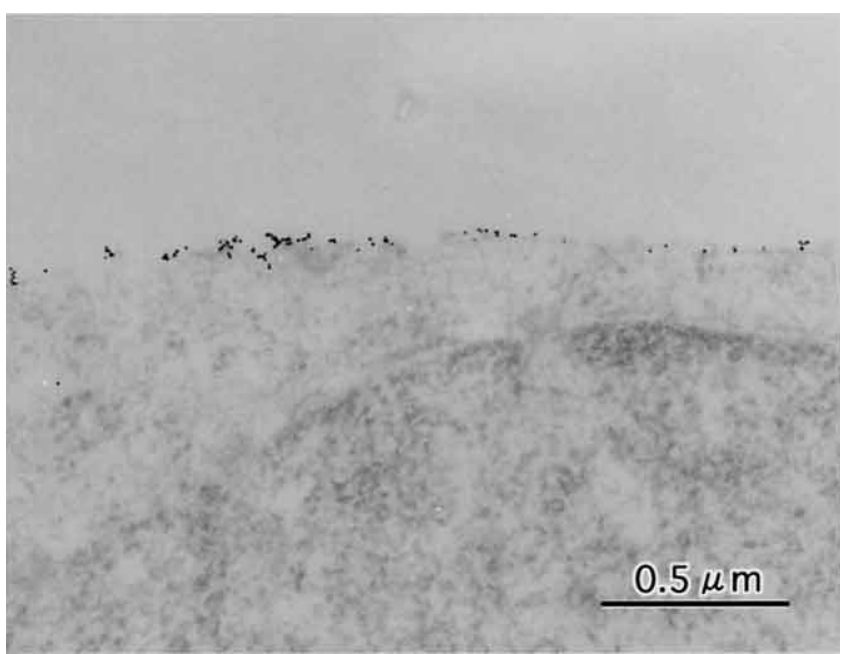

Fig. 8. Immuno-transmission electron microscopy (TEM) of insulin-like growth factor (IGF)-II/cation-independent mannose-6-phosphate (CI-M6P) receptors in primary cortical neurons. As with the second procedure in our immuno-SEM study, the anti-IGF-II/CIM6P receptor antibody was added to living neurons concurrently with IGF-II treatment before fixation. With the addition of IGF-II, gold particles were mostly seen in the cell surface of the neurons. Similarly, the labeling density of gold particles on the cell surface was highest at $1 \mathrm{hr}$ after the addition of IGF-II. This figure shows the labeling on the cell surface of the neuron fixed $1 \mathrm{hr}$ after the addition of both IGF-II and the antibody. Bar $=0.5 \mu \mathrm{m}$.

samples from the cerebral cortex. The samples showed a major immunoreactive band for IGF-II/CI-M6P receptors at the appropriate molecular weight of $300 \mathrm{kDa}$ (Fig. 9A, lane 1). The intensity of this band was significantly reduced when the blotted membrane was treated with the anti-IGFII/CI-M6P receptor antibody preabsorbed with the blocking peptide (Fig. 9A, lane 2). A couple of additional bands at lower molecular weights were observed (Fig. 9A, lane 1) and thought to depict fragments produced by destruction of the receptors when the cells were treated to obtain membrane fractions. No preabsorption of these additional bands was observed (Fig. 9A, lane 2). This may have possibly been due to the fact that the blocking peptide (sc-14414P; Santa Cruz) used for the preabsorption was a peptide mapping near the carboxy terminus of mouse IGF-IIR, whereas the anti-IGF-II/CI-M6P receptor antibody used in the present study was a polyclonal antibody raised against the whole length of the receptor.

With this antibody, the IGF-II/CI-M6P receptor was characterized using the membrane fractions from our primary cortical neurons treated with IGF-II. An IGF-II/CI-M6P receptor-immunoreactive band at the appropriate molecular weight of $300 \mathrm{kDa}$ was observed in the membranes from each sample of the neurons treated with IGF-II for $30 \mathrm{~min}$, and 1 and $3 \mathrm{hr}$, but not in those from the neurons untreated or treated for $15 \mathrm{~min}$ (Fig. 9B). As with the data in the immunoSEM and -TEM studies, our Western blot analysis data also indicated that exogenous IGF-II possibly induced its recep- tor expression on the cell surface of the neurons. The proteins loaded in each lane showed no significant variation in amount (Fig. 9C).

\section{Discussion}

Although several immunohistochemical studies of IGF-II/CI-M6P receptor distribution in the adult rat CNS have been reported [25-28], only faint or almost undetectable staining in the CNS parenchyma of unstimulated or unlesioned rats has been noted, providing no precise morphological information on subcellular localization, and occasionally leading to the opposite conclusion that cellular components other than neurons express IGF-II/CI-M6P receptors [27, 28]. However, Couce et al. [3] reported the highest immunostaining in the hippocampal neurons of adult rats. As Wylie et al. [29] noted, it seems to be now generally accepted that IGF-II/CI-M6P receptors are highly expressed in neurons of the forebrain, with the highest expression in the hippocampus and dentate gyrus. In the present study, we first made an immunohistochemical investigation of IGF-II/ CI-M6P receptors to precisely determine the cells expressing the receptors and their subcellular localization in the adult mouse CNS. This IGF-II/CI-M6P receptor immunoreactivity was distributed diffusely throughout the CNS, but observed mostly in areas where neuronal perikarya occur in tightly-packed clusters; it was not restricted to the hippocampus or dentate gyrus. By contrast, only a few glial cells were positively but weakly to moderately labeled. Under unstimulated or unlesioned conditions, IGF-II/CI-M6P receptor immunoreactivity in the adult CNS was almost wholly restricted to middle- to large-sized neurons. In addition, the immunoreactivity was largely localized within the cytoplasm in a granular pattern. Even with our immuno-EM of the brain tissues, this immunoreactivity was found to be localized within endosome-lysosomal structures of the neurons. It can then be concluded in the present study that there was more intense labeling in larger neurons that included more abundant endosome-lysosomal structures. Large pyramidal neurons have a well-developed and highly variegated lysosomal system to maintain huge cytoplasmic volumes and large expanses of membrane surface area [2]. Therefore, it is likely that the intensity of the IGF-II/CI-M6P receptor immunoreactivity demonstrated in the present study using CNS tissues is equivalent to the amounts of lysosomal enzymes sorted by IGF-II/CI-M6P receptors. We are now interested in investigating the immunoreactivity in the stimulated or lesioned CNS, in which larger numbers of glial cells and infiltrating cells are more intensely labeled [6].

However, we previously demonstrated that IGF-II augmented choline acetyltransferase (ChAT) activity in mouse primary septal neurons, and that this effect was considered to have been mediated via IGF-II/CI-M6P receptors because specific antibodies to the receptors abolished the effect [14]. Furthermore, as mentioned above, several reports have shown that IGF-II/CI-M6P receptors actually participate in 

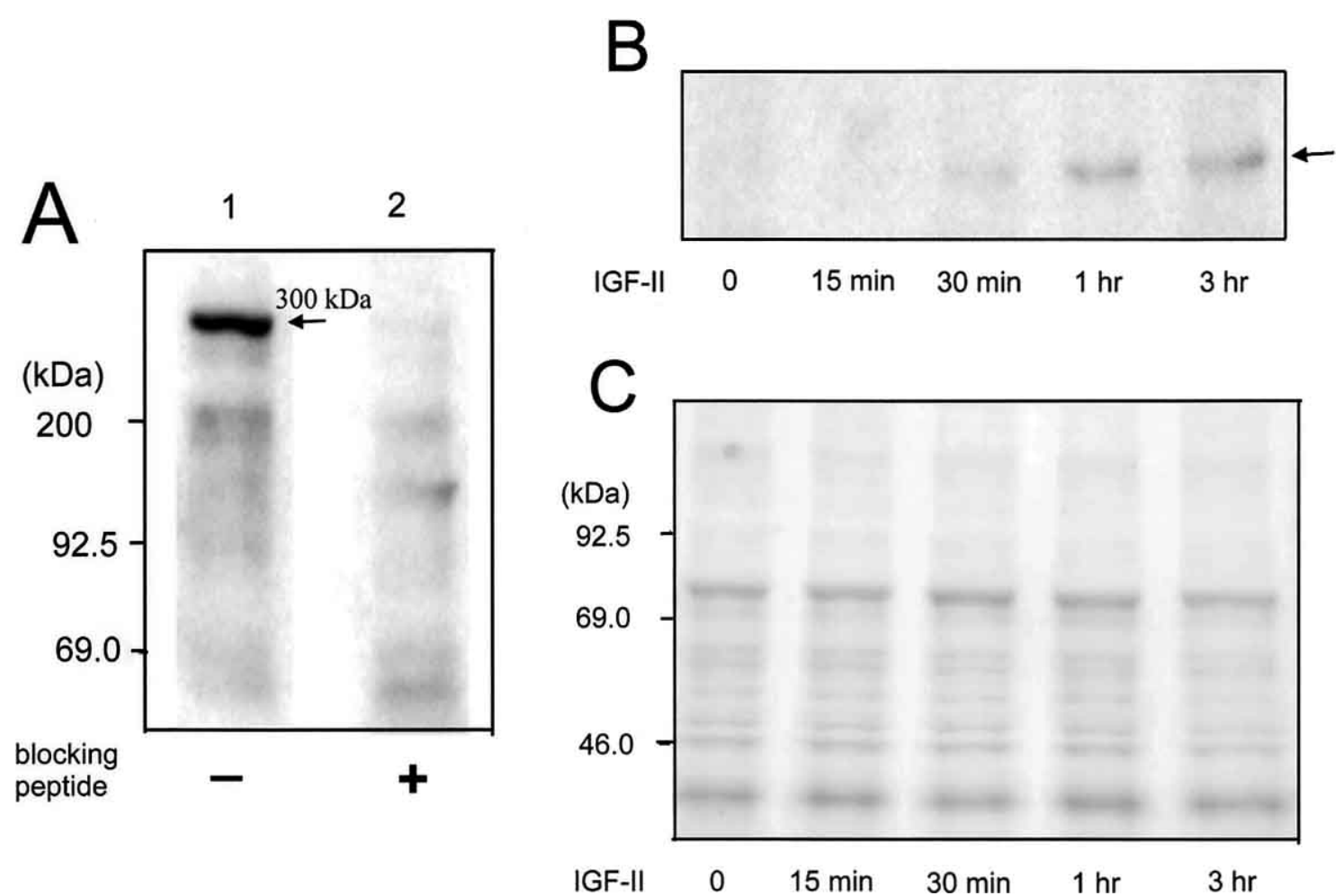

Fig. 9. Western blot analysis of insulin-like growth factor (IGF)-II/cation-independent mannose-6-phosphate (CI-M6P) receptors in mouse brain tissues and primary cortical neurons. A: With the IGF-II/CI-M6P receptor antibody provided by Dr. M. Himeno, Western blot analysis was performed on samples from the cerebral cortex of the adult mouse brain. A representative example is shown. Lane 1: A $20 \mu \mathrm{g}$ protein sample shows a major immunoreactive band for the IGF-II/CI-M6P receptors at the appropriate molecular weight of $300 \mathrm{kDa}$, as indicated by the arrow on the right in lane 1. Lane 2: The intensity of the band at $300 \mathrm{kDa}$ was significantly reduced when the blotted membrane was treated with the anti-IGFII/CI-M6P receptor antibody preabsorbed with the blocking peptide. B: With this antibody, IGF-II/CI-M6P receptor was characterized using the membrane fractions containing plasma membranes from the primary cortical neurons treated with IGF-II. An IGF-II/CI-M6P receptor-immunoreactive band at the appropriate molecular weight of $300 \mathrm{kDa}$ can be observed in the membrane from each sample of the neurons treated with IGF-II for $30 \mathrm{~min}$, and 1 and $3 \mathrm{hr}$, as indicated by the arrow on the right, but not in those without the treatment or with IGF-II for $15 \mathrm{~min}$. Similar to the data with the immuno-SEM (Figs. 6, 7) and -TEM (Fig. 8) studies, our Western blot analysis data also indicated that exogenous IGF-II induced its receptor expression possibly on the cell surface of the neurons. C: Protein staining with $0.2 \%$ ponseau $\mathrm{S}$ in $1 \%$ acetic acid solution was conducted on the blotted PVDF membrane used for the Western blot data shown in panel B. The positions of the molecular size markers (Rainbow colored protein molecular weight markers, Amersham) in $\mathrm{kDa}$ are indicated on the left in panels $\mathbf{A}$ and $\mathbf{C}$.

developing transmembrane IGF-II signals to target cells [11] and mediate the metabolic responses to IGF-II in neurons $[13,14]$ and in non-neuronal cells [19].

To address this issue, as the next step in the present study it was necessary to demonstrate the surface expression of IGF-II/CI-M6P receptors in neurons. With immunohistochemistry and immuno-EM using brain tissues, we were unable to detect IGF-II/CI-M6P receptor immunoreactivity in the cytoplasmic membrane. Therefore, we next used primary cortical neurons cultured from embryonic mouse CNS. It has been reported that most IGF-II receptors $(90 \%)$ are intracellularly present with a few $(10 \%)$ expressed in the cytoplasmic membrane [1]. This may possibly be because the number of receptors involved in the sorting within the cells is much greater than that involved in the development of exogenous IGF-II signals by surface expression, as suggested in the Results of our immunofluorescence study using cultured neurons. The endocytosis or internalization of recep- tors from the cell surface should also be carefully considered. Therefore, in the present study we treated cultured neurons with IGF-II to enhance the expression of IGF-II/CIM6P receptors in the cytoplasmic membrane. Furthermore, to detect IGF-II/CI-M6P receptors particularly on the cell surface of the neurons, two different immunocytochemical procedures were employed. The rationales behind these two techniques are described in detail in Materials and Methods. These two procedures in our immunofluorescence study showed a clear contrast in IGF-II/CI-M6P receptor-immunoreactivity patterns. As mentioned in the Results, most of the numerous immunoreactive granules present within the neuronal cell bodies and neurites obtained by the first immunofluorescence procedure (Fig. 5A) originated from IGF-II/ CI-M6P receptors involved in sorting lysosomal enzymes within the neurons but not in developing transmembrane IGF-II signals. In contrast, most of the positive immunoreactive granules obtained by the second immunofluorescence 
procedure (Fig. 5B) seemed to be localized within the neurons, and were considered to largely identify the receptors once expressed on the cell surface followed by internalization into the neurons. Even with the second procedure generally employed for examining endocytosis or internalization of receptors using living cells [9], hardly any IGF-IIR/CIM6P receptor-positive immunofluorescence was found on the cell surface of neurons treated with IGF-II. We conjectured that our failure to detect or demonstrate the receptors in the cell surface with fluorescence microscopy might have been due to the possibility that the labeling intensity and density in the cell surface was under the detection level. Actually, there may possibly have been a few immunoreactive granules on the cell surface (arrow in Fig. 5B), but we could not find evidence of unequivocal subcellular localization, particularly in the plasma membrane, with our observation of a whole cell by fluorescence microscopy.

Therefore, to precisely determine subcellular localization, particularly the difference between surface and intracellular localizations, we conducted a more specific immuno-SEM study, using primary cultured neurons treated with IGF-II. The two immunocytochemical procedures were employed again in this further immuno-SEM study. Our SEM study demonstrated that IGF-II induced the expression of its receptors in the neuronal cell surface. This could be demonstrated with both procedures, although the second one was able to depict a more remarkable increase in the receptors expressed on the cell surface on exposure to IGF-II with a less intense non-specific staining. The results of our SEM study were consistent with the data in our Western blot analysis using membrane fractions. Our second procedure is a good method to observe the temporal expression of receptors on the cell surface. However, we should also entertain the possibility that receptor antibodies directly stimulate cells to induce receptor expression on the cell surface, although it can be ruled out in the present study, as mentioned in the Results of our immuno-SEM study using cultured neurons.

In conclusion, the IGF-II/CI-M6P receptors present in the neurons are thought to partly function to develop transmembrane IGF-II signals by their expression in the neuronal cytoplasmic membrane. Of course, the IGF-II/CI-M6P receptors may function as non-signaling receptors to sort or scavenge excess amounts of exogenous IGF-II [5], even if expressed in the plasma membrane. Therefore, further examinations of the molecules involved in intracellular signaling pathways following the initial binding of the ligands to their receptors are necessary.

Recently, Hawkes and Kar [8] reported a widespread distribution of IGF-II/CI-M6P receptors in neurons of the adult rat $\mathrm{CNS}$. The cellular distribution of the receptor immunoreactivity they reported is almost the same as that in our present immunohistochemical study using adult mouse CNS. However, we observed that the receptor immunoreactivity in neurons had a granular appearance, which was not mentioned by Hawkes and Kar [8]. Considering our immunohistochemistry and immuno-EM data using CNS tissues, we have further provided here morphological information on the subcellular localization of IGF-II/CI-M6P receptors in neurons, as mentioned at the beginning of the Discussion. Briefly, it is likely that the IGF-II/CI-M6P receptor-immunoreactive granules depict endosome-lysosomal structures particularly in unstimulated or unlesioned neurons. In addition, we found IGF-II/CI-M6P receptor immunoreactivity in glial cells, although only a small number were weakly to moderately labeled. Hawkes and Kar [8], however, reported no immunoreactivity in morphologically identifiable glial cells in the adult rat CNS. Furthermore, with immuno-EM, we first found IGF-II/CI-M6P receptors expressed in the cytoplasmic membrane of primary cultured cortical neurons treated with IGF-II. The data shown herein was partly presented at the 26th Annual Meeting of the Society for Neuroscience in Washington, D.C. (Abstr. Soc. Neurosci. 22, 552, 1996).

\section{Acknowledgments}

We thank Dr. Masaru Himeno (Kyushu University, Japan) for the gift of anti-IGF-II/CI-M6P receptor antibody. This work was supported in part by a Research Project Grant (10-704) from Kawasaki Medical School.

\section{References}

1. Braulke, T. (1999) Type-2 IGF receptor: A multi-ligand binding protein. Horm. Metab. Res. 31; 242-246.

2. Cataldo, A. M., Hamilton, D. J., Barnett, J. L., Paskevich, P. A. and Nixon, R. A. (1996) Properties of the endosomal-lysosomal system in the human central nervous system: Disturbances mark most neurons in populations at risk to degenerate in Alzheimer's disease. J. Neurosci. 16; 186-199.

3. Couce, M. E., Weatherington, A. J. and McGinty, J. F. (1992) Expression of insulin-like growth factor-II (IGF-II) and IGF-II/ mannose-6-phosphate receptor in the rat hippocampus: An in situ hybridization and immunocytochemical study. Endocrinology $131 ; 1636-1642$.

4. D'Ercole, A. J., Ye, P., Calikoglu, A. S. and Gutierrez-Ospina, G. (1996) The role of the insulin-like growth factors in the central nervous system. Mol. Neurobiol. 13;227-255.

5. Folli, F., Ghidella, S., Bonfanti, L., Kahn, C. R. and Merighi, A. (1996) The early intracellular signaling pathway for the insulin/ insulin-like growth factor receptor family in the mammalian central nervous system. Mol. Neurobiol. 13; 155-183.

6. Fushimi, S. and Shirabe, T. (2004) The expression of insulin-like growth factors (IGF-I, -II) in remyelination following ethidium bromide-induced demyelination in mouse spinal cord. Neuropathol. (in press)

7. Gammeltoft, S., Christiansen, J., Nielsen, F. C. and Verland, S. (1991) Insulin-like growth factor II: Complexity of biosynthesis and receptor binding. In "Molecular Biology and Physiology of Insulin and Insulin-like Growth Factors", ed. by M. K. Raizada and D. LeRoith, Plenum Press, New York, pp. 31-44.

8. Hawkes, C. and Kar, S. (2003) Insulin-like growth factor-II/mannose-6-phophate receptor: Widespread distribution in neurons of the central nervous system including those expressing cholinergic phenotype. J. Comp. Neurol. 458; 113-127.

9. Hémar, A., Subtil, A., Lieb, M., Morelon, E., Hellio, R. and Dautry-Varsat, A. (1995) Endocytosis of interleukin 2 receptors in human T lymphocytes: Distinct intracellular localization and 
fate of the receptor $\alpha, \beta$, and $\gamma$ chains. J. Cell Biol. 129; 55-64.

10. Hepler, J. E. and Lund, P. K. (1990) Molecular biology of the insulin-like growth factors. Relevance to nervous system function. Mol. Neurobiol. 4; 93-127.

11. Ikezu, T., Okamoto, T., Giambarella, U., Yokota, T. and Nishimoto, I. (1995) In vivo coupling of insulin-like growth factor II/ mannose 6-phosphate receptor to heteromeric G proteins. Distinct roles of cytoplasmic domains and signal sequestration by the receptor. J. Biol. Chem. 270; 29224-29228.

12. Kamegai, M., Niijima, K., Kunishita, T., Nishizawa, M., Ogawa, M., Araki, M., Ueki, A., Konishi, Y. and Tabira, T. (1990) Interleukin 3 as a trophic factor for central cholinergic neurons in vitro and in vivo. Neuron $4 ; 429-436$.

13. Kar, S., Seto, D., Doré, S., Hanisch, U.-K. and Quirion, R. (1997) Insulin-like growth factors-I and -II differentially regulate endogenous acetylcholine release from the rat hippocampal formation. Proc. Natl. Acad. Sci. U S A 94; 14054-14059.

14. Konishi, Y., Takahashi, K., Chui, D.-H., Rosenfeld, R. G., Himeno, M. and Tabira, T. (1994) Insulin-like growth factor II promotes in vitro cholinergic development of mouse septal neurons: Comparison with the effects of insulin-like growth factor I. Brain Res. 649; 53-61.

15. Konishi, Y., Chui, D.-H., Kunishita, T., Yamamura, T., Higashi, Y. and Tabira, T. (1995) Demonstration of interleukin-3 receptorassociated antigen in the central nervous system. J. Neurosci. Res. 41; 572-582.

16. Kunishita, T., Ikeda, S., Araki, W. and Tabira, T. (1994) The decrement of muscarinic receptor-mediated calcium influx by overexpression of APP in a mouse cholinergic cell line. Tohoku J. Exp. Med. 174; 225-239.

17. Ludwig, T., Le Borgne, R. and Hoflack, B. (1995) Roles for mannose-6-phosphate receptors in lysosomal enzyme sorting, IGF-II binding and clathrin-coat assembly. Trends Cell Biol. 5; 202-206.

18. MacDonald, R. G., Pfeffer, S. R., Coussens, L., Tepper, M. A., Brocklebank, C. M., Mole, J. E., Anderson, J. K., Chen, E., Czech, M. P. and Ullrich, A. (1988) A single receptor binds both insulin-like growth factor II and mannose-6-phosphate. Science 239; 1134-1137.

19. Minniti, C. P., Kohn, E. C., Grubb, J. H., Sly, W. S., Oh, Y., Müller, H. L., Rosenfeld, R. G. and Helman, L. J. (1992) The insulin-like growth factor II (IGF-II)/mannose 6-phosphate receptor mediates IGF-II-induced motility in human rhabdomyosarcoma cells. J. Biol. Chem. 267; 9000-9004.
20. Nielsen, F. C. and Gammeltoft, S. (1990) Mannose-6-phophate stimulates proliferation of neuronal precursor cells. FEBS Lett. $262 ; 142-144$.

21. Nilsson, C., Hultberg, B. M. and Gammeltoft, S. (1996) Autocrine role of insulin-like growth factor II secretion by the rat choroid plexus. Eur. J. Neurosci. 8; 629-635.

22. Roth, R. A. (1988) Structure of the receptor for insulin-like growth factor II: The puzzle amplified. Science 239; 1269-1271.

23. Rotwein, P., Burgess, S. K., Milbrandt, J. D. and Krause, J. E. (1988) Differential expression of insulin-like growth factor genes in rat central nervous system. Proc. Natl. Acad. Sci. U S A 85; 265-269.

24. Sahagian, G. G., Distler, J. J. and Jourdian, G. W. (1982) Membrane receptor for phosphomannosyl residues. Methods Enzymol. 83; 392-396.

25. Senior, P. V., Byrne, S., Brammar, W. J. and Beck, F. (1990) Expression of the IGF-II/mannose-6-phosphate receptor mRNA and protein in the developing rat. Development $109 ; 67-73$.

26. Stephenson, D. T., Rash, K. and Clemens, J. A. (1995) Increase in insulin-like growth factor II receptor within ischemic neurons following focal cerebral infarction. J. Cereb. Blood Flow Metab. $15 ; 1022-1031$.

27. Valentino, K. L., Pham, H., Ocrant, I. and Rosenfeld, R. G. (1988) Distribution of insulin-like growth factor II receptor immunoreactivity in rat tissues. Endocrinology 122; 2753-2763.

28. Valentino, K. L., Ocrant, I. and Rosenfeld, R. G. (1990) Developmental expression of insulin-like growth factor-II receptor immunoreactivity in the rat central nervous system. Endocrinology 126; 914-920.

29. Wylie, A. A., Pulford, D. J., McVie-Wylie, A. J., Waterland, R. A., Evans, H. K., Chen, Y.-T., Nolan, C. M., Orton, T. C. and Jirtle, R. L. (2003) Tissue-specific inactivation of murine M6P/ IGF2R. Am. J. Pathol. 162; 321-328.

30. Yamada, S., Sugai, M., Komatsuzawa, H., Nakashima, S., Oshida, T., Matsumoto, A. and Suginaka, H. (1996) An autolysin ring associated with cell separation of Staphylococcus aureus. J. Bacteriol. 178; 1565-1571.

31. Yang, L.-B., Lindholm, K., Konishi, Y., Li, R. and Shen, Y. (2002) Target depletion of distinct tumor necrosis factor receptor subtypes reveals hippocampal neuron death and survival through different signal transduction pathways. J. Neurosci. 22; 30253032 . 